\title{
Faktor-Faktor Yang Mempengaruhi Nilai Perusahaan Dengan Moderasi GCG
}

\author{
Henny Wirianata \\ Fakultas Ekonomi dan Bisnis, Universitas Tarumanagara \\ Email: hennyw@fe.untar.ac.id
}

\begin{abstract}
The objective of this study is to obtain empirical evidence about the influence of capital structure, profitability, firm size, and good corporate governance (GCG) towards firm value of manufacturing companies listed in Indonesia Stock Exchange period 2016 2018. The data were tested in this research using EVIEWS 10. The results show that capital structure proxies by DER and profitability proxies by NPM have positive and significant effect towards firm value. Meanwhile, profitability proxies by ROA, firm size, and GCG proxies by institutional ownership have negative and significant effects towards firm value. The results also show that institutional ownership could not moderated the effects of capital structure, profitability, and firm size towards firm value of manufacturing companies listed in Indonesia Stock Exchange period 2016-2018.
\end{abstract}

Keywords: Capital Structure, Profitability, Firm Size, Institutional Ownership, Firm Value.

Abstrak: Penelitian ini bertujuan untuk memperoleh bukti empiris mengenai pengaruh struktur modal, profitabilitas, ukuran perusahaan, dan good corporate governance (GCG) terhadap nilai perusahaan pada industri manufaktur yang terdaftar di Bursa Efek Indonesia (BEI) periode 2016-2018. Data dalam penelitian ini diolah dengan menggunakan program EVIEWS 10. Hasil dari penelitian ini menunjukkan bahwa struktur modal yang diproksikan dengan DER dan profitabilitas yang diproksikan dengan NPM memiliki pengaruh positif dan signifikan terhadap nilai perusahaan. Sementara, profitabilitas yang diproksikan dengan ROA, ukuran perusahaan, dan GCG yang diproksikan dengan kepemilikan institusional memiliki pengaruh negatif dan signifikan terhadap nilai perusahaan. Hasil penelitian juga menunjukkan bahwa kepemilikan institusional tidak dapat memoderasi pengaruh struktur modal, profitabilitas, dan ukuran perusahaan terhadap nilai perusahaan manufaktur yang terdaftar di Bursa Efek Indonesia (BEI) periode 2016-2018.

Kata Kunci: Struktur Modal, Profitabilitas, Ukuran Perusahaan, Kepemilikan Institusional, Nilai Perusahaan.

\section{PENDAHULUAN}

Perkembangan dunia usaha yang pesat mendorong timbulnya persaingan bisnis yang ketat. Pimpinan dan manajer dituntut untuk mampu mengelola keuangan perusahaan dengan baik dan efisien. Nilai perusahaan menjadi salah satu alat ukur untuk menilai kesuksesan 
pimpinan dan manajer dalam mengelola keuangan perusahaan. Para pemegang saham menginginkan nilai perusahaan yang tinggi. Nilai perusahaan yang tinggi mencerminkan nilai saham yang tinggi, sehingga dianggap akan memberikan kesejahteraan yang tinggi kepada para pemegang saham.

Nilai perusahaan menjadi informasi penting yang memperlihatkan kinerja perusahaan yang akan mempengaruhi penilaian para investor terhadap perusahaan (Purwanto and Agustin, 2017). Perusahaan dengan prospek kinerja keuangan yang baik akan mendorong investor untuk berinvestasi yang pada akhirnya akan meningkatkan nilai pasar saham perusahaan (Luthfiah dan Suherman, 2018). Jika nilai saham naik, maka akan memberikan pengaruh positif tidak hanya bagi perusahaan tetapi juga memberikan tingkat pengembalian yang tinggi bagi para pemegang saham (Luthfiah dan Suherman, 2018).

Salah satu tolok ukur menentukan nilai perusahaan adalah dengan menggunakan Price to Book Value (PBV). PBV mencerminkan nilai yang dapat diciptakan oleh perusahaan bagi para pemegang saham atas setiap dana yang diinvestasikan mereka dalam perusahaan. Perusahaan dengan rasio PBV yang tinggi menunjukkan perusahaan berhasil dalam menciptakan nilai bagi pemegang saham yang ditunjukkan dari nilai saham yang tinggi (Salim dan Susilowati, 2019). Sebaliknya rasio PBV yang rendah akan mencerminkan nilai saham yang rendah.

Investor menilai kinerja perusahaan dengan melihat pada rasio-rasio keuangan. Jika nilai-nilai rasio keuangan dapat memberikan sinyal positif kepada investor maka akan mendorong peningkatan pada nilai pasar saham dan nilai perusahaan. Nilai-nilai rasio keuangan yang menjadi faktor yang dapat mempengaruhi nilai perusahaan, diantaranya struktur modal (capital structure), profitabilitas (profitability), dan ukuran perusahaan (firm size). Nilai perusahaan juga dapat dipengaruhi oleh nilai-nilai non keuangan, seperti adanya tata kelola yang baik (Good Corporate Governance/GCG) dalam perusahaan. Tata kelola dalam perusahaan (corporate governance) akan meningkatkan efisiensi kinerja manajemen, pertumbuhan ekonomi perusahaan, dan juga meningkatkan kepercayaan investor kepada perusahaan (Wimelda dan Siregar, 2017).

Para pemegang saham akan memiliki kepentingan yang berbeda dengan manajemen perusahaan. Manajemen, sebagai agen, memiliki kepentingan dengan menentukan kebijakan yang dapat meningkatkan kesejahteraan mereka. Sementara, pemegang saham sebagai principal menginginkan manajemen menetapkan kebijakan yang mensejahterakan pemegang saham melalui peningkatan nilai perusahaan (Wimelda dan Siregar, 2017). Untuk meningkatkan pengawasan dalam proses manajerial dan kinerja perusahaan, salah satu caranya adalah dengan menerapkan praktek GCG, yang ditunjukkan dari adanya kepemilikan institusional sebagai bagian dari pemegang saham (Vintila dan Gherghina, 2014).

Penelitian ini menggunakan sampel perusahaan sektor industri manufaktur. Tahun 2018, Indonesia menempati peringkat keempat dunia dari lima belas negara yang industri manufakturnya memberikan kontribusi besar terhadap Produk Domestik Bruto (PDB) dimana Indonesia mampu menyumbang hingga 22\% setelah Korea Selatan (29\%), Tiongkok (27\%), dan Jerman (23\%). United Nations Industrial Development Organization (UNIDO) mencatat, Indonesia menduduki peringkat ke sembilan di dunia untuk kategori Manufacturing Value Added. Peringkat tersebut naik dari peringkat tahun sebelumnya yaitu di posisi ke sepuluh. Peringkat ke sembilan ini sejajar dengan Brazil dan Inggris, bahkan 
lebih tinggi dari Rusia, Australia, dan Negara ASEAN lainnya (https://industri.kontan.co.id/news/sektor-manufaktur-ini-jadi-andalan-di-tahun-2018).

Gambar 1. PMI BI dan Pertumbuhan PDB Industri Pengolahan/Manufaktur

\section{Grafik 1 Prompt Manufacturing index (PMI) - Bl dan Pertumbuhan Triwulanan PDB Industri Pengolahan}

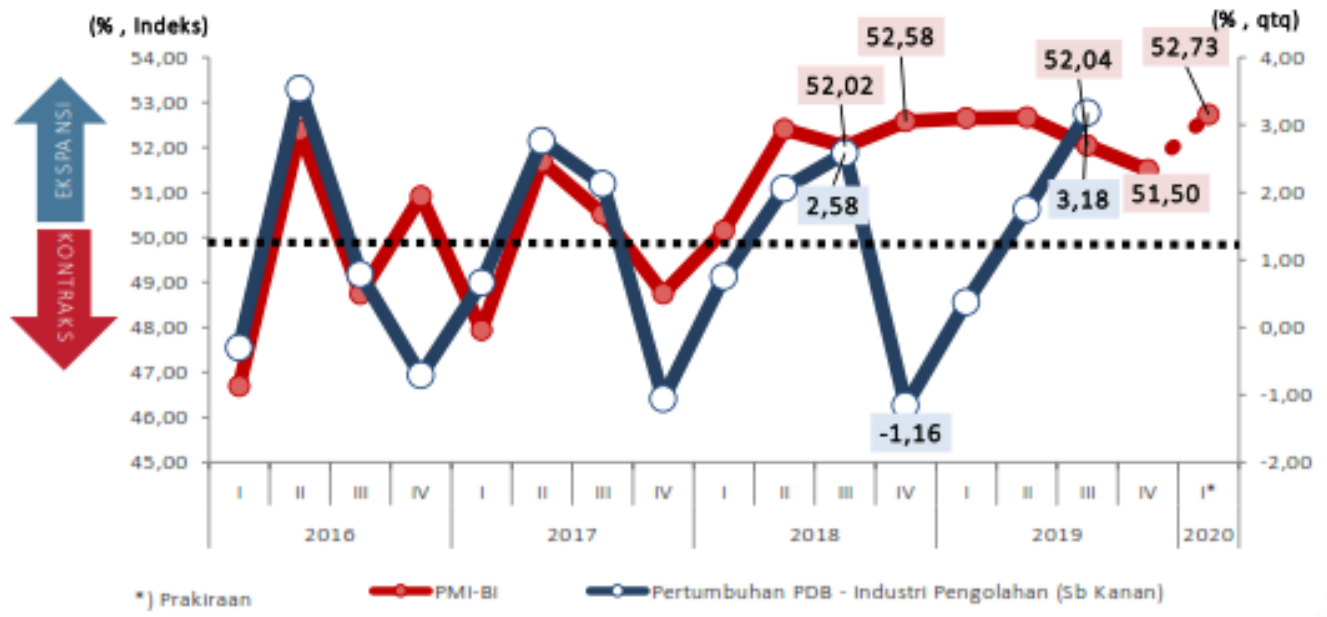

Sumber: (https://www.bi.go.id/id/publikasi/survei/PromptManufacturingIndex/Pages/pmi-triwulan-IV-2019.aspx, 2019)

Prompt Manufacturing Index-Bank Indonesia (PMI-BI) adalah sebuah indikator yang menyediakan gambaran umum mengenai kondisi Sektor Industri Pengolahan yang diperoleh dari lima indeks yaitu volume pesanan barang input, volume produksi (output), ketenagakerjaan, waktu pengiriman dari pemasok, dan inventori (https://www.bi.go.id/publikasi/survei/Prompt-Manufacturing-Index/Default.aspx).

Kinerja industri manufaktur diperkirakan akan meningkat di tahun 2020 ini. Hal tersebut terindikasi dari PMI Bank Indonesia pada tiga bulan pertama di tahun 2020 yang diperkirakan meningkat menjadi 52,73\% (lihat Gambar 2). Perkembangan PMI-BI tersebut sejalan dengan perkembangan kegiatan usaha sektor Industri Pengolahan hasil Survei Kegiatan Dunia Usaha (SKDU), yang menunjukkan realisasi kegiatan usaha yang kembali meningkat di tiga bulan pertama tahun 2020 (lihat Gambar 3) (https://www.bi.go.id/id/publikasi/survei/Prompt-Manufacturing Index/Pages/pmitriwulanIV-2019.aspx). 
Gambar 2. PMI BI dan SBT SKDU Industri Pengolahan/Manufaktur

\section{Grafik 2 Prompt Manufacturing index (PMI)-BI \& SBT SKDU Industri Pengolahan}

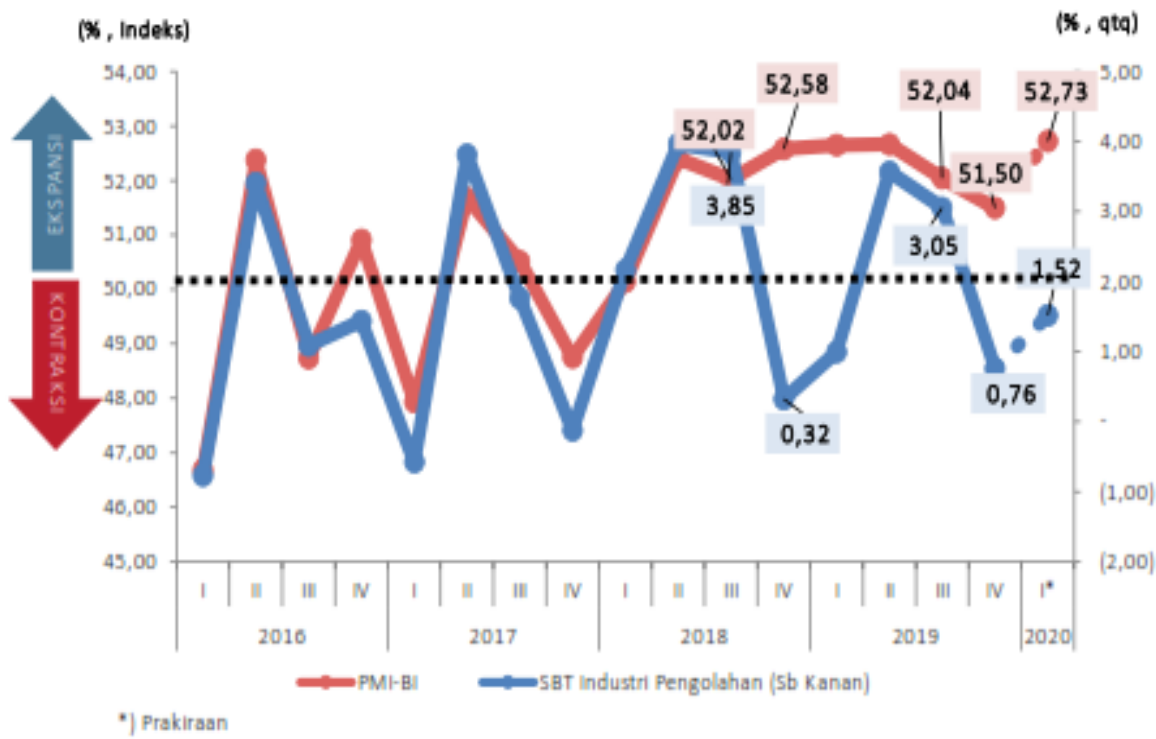

Sumber: (https://www.bi.go.id/id/publikasi/survei/Prompt-Manufacturing $\underline{\text { Index/Pages/pmi-triwulan-IV-2019.aspx, 2019) }}$

Oleh karena itu dapat disimpulkan bahwa industri manufaktur Indonesia adalah salah satu industri yang saat ini memiliki trend mengalami peningkatan. Dengan kinerja industri manufaktur yang meningkat, maka perusahaan di industri manufaktur dituntut untuk dapat menjaga dan meningkatkan nilai dari perusahaan sehingga bisa tetap menumbuhkan kepercayaan dan memberikan keyakinan kepada para investor untuk terus berinvestasi dalam perusahaan.

Berdasarkan uraian di atas, informasi mengenai nilai perusahaan menjadi salah satu faktor penting bagi investor dalam mengambil keputusan investasi dan bagi peningkatan kesejahteraan pemegang saham. Penelitian ini bertujuan untuk mendapatkan bukti empiris yang dapat menjelaskan pengaruh struktur modal, profitabilitas, ukuran perusahaan, dan GCG terhadap nilai perusahaan manufaktur yang terdaftar di BEI tahun 2016-2018. Penelitian ini juga akan menguji peran GCG sebagai variabel moderasi atas pengaruh struktur modal, profitabilitas, dan ukuran perusahaan terhadap nilai perusahaan manufaktur yang terdaftar di BEI tahun 2016-2018.

\section{KAJIAN TEORI}

Teori Sinyal (Signaling Theory). Teori sinyal menekankan bahwa informasi yang dipublikasikan perusahaan memiliki peran penting bagi para investor di luar perusahaan (Luthfiah dan Suherman, 2018). Informasi tersebut dapat dalam bentuk Laporan Keuangan 
ataupun publikasi informasi lainnya dapat mempengaruhi pengambilan keputusan investor. Teori sinyal dapat diartikan sebagai efek yang timbul dari pengumuman laporan keuangan dimana efek tersebut dapat dijadikan ancaman maupun peluang oleh para pelaku pasar dalam mengambil keputusan investasi (Penman, 2003).

Teori sinyal dipandang dapat memberikan pemahaman mengenai kenaikan dan penurunan harga yang terjadi di pasar, sehingga keputusan investor dalam berinvestasi akan sangat terpengaruhi oleh sinyal yang diperoleh (Fahmi, 2015). Informasi yang dimiliki oleh pihak manajemen mengenai internal perusahaan maupun informasi yang terjadi dipasar berfungsi untuk membantu pihak manajemen dalam membuat keputusan yang dapat meningkatkan nilai perusahaan. Manajemen perusahaan harus menetapkan secara bijak informasi-informasi yang dapat memberikan kemudahan dalam mengambil keputusan baik untuk internal perusahaan maupun untuk investor, sehingga keputusan yang diambil akan berdampak positif terhadap nilai perusahaan.

Teori Agensi (Agency Theory). Teori agensi menjelaskan kontrak antara prinsipal (pemilik) dengan agen (manajemen). Masalah keagenan timbul ketika agen, yaitu manajemen, yang harus bertindak untuk kepentingan prinsipal, tetapi seringkali manajemen bertindak untuk kepentingan mereka pribadi (Jensen dan Meckling, 1976). Sebagai prinsipal, jika pemegang saham adalah pemegang saham individu, mereka tidak dapat mengawasi manajemen secara maksimal. Begitu pula jika pemegang saham mayoritas adalah juga berfungsi sebagai manajemen perusahaan, maka manajemen akan bertindak untuk kepentingan mereka dan merugikan pemegang saham minoritas (Wimelda dan Siregar, 2017).

Prinsipal harus mengeluarkan biaya agensi (agency cost) yaitu biaya pengawasan (controlling cost) untuk membatasi tindakan manajemen agar sesuai dengan kepentingan prinsipal (Wimelda dan Siregar, 2017). Biaya agensi yang tinggi menggambarkan ketidakharmonisan hubungan antara prinsipal dengan agen. Sebaliknya, semakin rendah biaya agensi, semakin optimal hubungan antara prinsipal dan agen (Wimelda dan Siregar, 2017). Jika biaya agensi rendah maka akan mendorong meningkatnya nilai perusahaan (Manurung et al., 2014).

Nilai Perusahaan. Nilai perusahaan (Firm Value) merupakan pandangan para investor yang mengaitkan harga saham dengan tingkat keberhasilan suatu perusahaan (Sujoko dan Soebiantoro, 2007). Jika harga saham perusahaan tinggi maka dikatakan nilai perusahaan juga akan meningkat. Nilai perusahaan akan mengalami penurunan apabila harga saham dari perusahaan berada pada nilai yang tergolong rendah.

Semakin besar nilai perusahaan berarti semakin baik kondisi keuangan perusahaan dan prospek perusahaan (Rajhans, 2013). Perusahaan yang sudah go-public memiliki tujuan jangka panjang untuk memaksimalkan kesejahteraan para pemegang saham, yang ditunjukkan dari nilai saham (Salim dan Susilowati, 2019). Oleh karena itu, rasio nilai pasar saham dapat menjadi tolok ukur untuk menentukan nilai perusahaan.

Nilai perusahaan dalam penelitian ini diproksikan dengan Price to Book Value Ratio (PBV). PBV menghitung nilai perusahaan dari perbandingan harga pasar saham dengan nilai buku perusahaan. (Purwanto dan Agustin, 2017) menjelaskan bahwa harga saham mencerminkan nilai yang akan dibayarkan para investor sebagai bukti atas kepemilikannya 
di perusahaan. Sehingga, rasio nilai saham yang tinggi pada suatu perusahaan dapat mendorong para investor tidak merasa ragu dalam melakukan investasi dana karena memiliki kepercayaan bahwa perusahaan akan lebih berkembang di waktu yang akan datang. Pemegang saham pun akan senantiasa memantau pergerakan harga saham karena kesejahteraan mereka ditentukan dari harga saham (Purwanto dan Agustin, 2017).

Struktur Modal dan Pengaruhnya Terhadap Nilai Perusahaan. Struktur modal menggambarkan proporsi sumber dana perusahaan. Struktur modal dapat diukur dengan menggunakan rasio total hutang terhadap total ekuitas, yaitu Debt to Equity Ratio (DER). (Sutrisno, 2016) menyatakan bahwa semakin tinggi nilai DER menunjukkan semakin tinggi perusahaan bergantung pada pendanaan dari luar perusahaan. Hutang perusahaan akan meningkatkan beban perusahaan karena harus membayar bunga, kondisi ini dapat menurunkan profitabilitas perusahaan dan mempengaruhi nilai perusahaan. Namun, di sisi lain beban bunga dapat menurunkan beban pajak yang harus dibayarkan perusahaan. Dengan adanya penghematan pajak, perusahaan dapat memaksimalkan penggunaan aset untuk membayar deviden bagi pemegang saham, yang berarti akan mendorong peningkatan harga saham perusahaan. Dengan demikian, kebijakan pendanaan perusahaan dalam menentukan struktur modal yang memaksimumkan kinerja perusahaan akan berpengaruh terhadap nilai perusahaan (Salim dan Susilowati, 2019).

(Chasanah dan Adhi, 2017), (Indasari dan Yadnyana, 2018), (Susanti dan Restiana, 2018), serta (Wahyu dan Mahfud, 2018), dalam penelitiannya menemukan bahwa struktur modal memiliki pengaruh positif dan signifikan terhadap nilai perusahaan. Dalam penelitiannya, (Wahyu dan Mahfud, 2018) menemukan bahwa keputusan pendanaan dengan menggunakan hutang lebih diminati oleh investor yang berarti pendanaan dengan hutang dianggap memberikan manfaat yang lebih besar daripada beban yang ditimbulkan. Dengan demikian, penggunaan hutang dianggap tidak akan menurunkan harga saham, sehingga peningkatan DER akan dapat meningkatkan nilai perusahaan (Wahyu dan Mahfud, 2018).

(Purwanto dan Agustin, 2017) menemukan bahwa struktur modal memberikan pengaruh negatif dan signifikan terhadap nilai perusahaan. Beban bunga yang timbul dari penggunaan hutang akan mengurangi beban pajak perusahaan. Namun, penggunaan dana dari hutang yang berlebihan akan membawa perusahaan pada resiko kebangkrutan karena perusahaan harus membayar pokok hutang dan bunga (Purwanto dan Agustin, 2017). Hal ini berarti peningkatan pada nilai DER akan mengakibatkan penurunan pada nilai perusahaan. (Lubis et al., 2017) serta (Salim dan Susilowati, 2019) menemukan bahwa struktur modal tidak berpengaruh terhadap nilai perusahaan. Keberadaan hutang tidak mempengaruhi nilai perusahaan karena perusahaan dianggap telah mendapatkan pendanaan yang cukup dari laba ditahan dan modal saham, dan bukan dari hutang.

Profitabilitas dan Pengaruhnya Terhadap Nilai Perusahaan. Profitabilitas merupakan kinerja keuangan yang paling sering digunakan investor untuk mengetahui nilai perusahaan. Profitabilitas adalah kemampuan perusahaan dalam menghasilkan laba yang dikaitkan dengan tingkat penjualan, total aset, dan total modal perusahaan (Sartono, 2010). Semakin tinggi laba yang dihasilkan perusahaan berarti semakin efektif dan semakin efisien 
perusahaan mengelola kekayaannya untuk menghasilkan return bagi pemegang saham, yang akan mengakibatkan nilai perusahaan meningkat (Suwardika dan Mustanda, 2017).

Profitabilitas dapat diukur dengan Return on Assets (ROA) dan Net Profit Margin (NPM). Semakin tinggi nilai ROA dan NPM berarti semakin tinggi kemampuan perusahaan dalam menghasilkan laba yang dibandingkan dengan total aset dan hasil penjualan perusahaan. Perusahaan dengan nilai profitabilitas yang tinggi akan mampu mengurangi penggunaan pendanaan dari hutang karena perusahaan memiliki pendanaan internal yang cukup dari peningkatan laba ditahan (Salim dan Susilowaty, 2019).

Hasil penelitian (Chasanah dan Adhi, 2017), (Indasari dan Yadnyana, 2018), (Salim dan Susilowati, 2019), (Suwardika dan Mustanda, 2017), (Taufan et al., 2018), serta (Wahyu dan Mahfud, 2018) menemukan bahwa ROA memberikan pengaruh positif dan signifikan terhadap nilai perusahaan. Hal ini berarti nilai ROA yang tinggi akan meningkatkan nilai saham dan nilai perusahaan.

(Munawaroh dan Priyadi, 2014) dan (Yastini dan Mertha, 2015) menemukan bahwa ROA memberikan pengaruh negatif dan signifikan terhadap ROA yang berarti jika nilai ROA meningkat maka akan menurunkan nilai perusahaan. (Yastini dan Mertha, 2015) menyatakan bahwa peningkatan profitabilitas akan menaikkan laba per saham tetapi tidak secara langsung meningkatkan harga saham, sehingga akan berdampak pada penurunan nilai perusahaan.

(Munawaroh dan Priyadi, 2014) dan (Wahyu dan Mahfud, 2018) dalam penelitiannya menemukan bahwa NPM memiliki pengaruh positif dan signifikan terhadap nilai perusahaan. NPM yang meningkat menunjukkan kinerja perusahaan yang produktif yang berarti manajemen mampu meminimalkan biaya dan memaksimalkan laba (Wahyu dan Mahfud, 2018). Hal ini akan menjadi sinyal positif bagi investor sehingga mendorong harga saham naik dan nilai perusahaan meningkat. Hasil penelitian (Susanti dan Restiana, 2018) menemukan bahwa NPM memberikan pengaruh negatif dan signifikan. NPM menunjukkan kemampuan perusahaan menghasilkan laba dari aktivitas penjualan, sehingga berpengaruh terhadap pertumbuhan perusahaan dan bukan terhadap nilai perusahaan (Susanti dan Restiana, 2018).

Ukuran Perusahaan dan Pengaruhnya Terhadap Nilai Perusahaan. Menurut (Hansen dan Juniarti, 2014), ukuran perusahaan ialah rasio yang menjelaskan tentang besarnya aset yang dimiliki suatu perusahaan yang diukur dari besarnya total penjualan perusahaan, aktiva perusahaan, rata-rata tingkat penjualan perusahaan, dan rata-rata total aktiva yang dimiliki perusahaan. (Luthfiah dan Suherman, 2018), menyebutkan bahwa ukuran perusahaan dapat dilihat dari total aset milik perusahaan yang dapat digunakan dalam aktivitas operasi perusahaan.

Ukuran Perusahaan dapat dikategorikan menjadi perusahaan besar, perusahaan sedang, dan perusahaan kecil (Susanti dan Restiana, 2018). Perusahaan dengan total aset yang besar memiliki kemampuan untuk menggunakan seluruh aset tersebut dalam memaksimalkan laba perusahaan sehingga memberikan tingkat pengembalian yang tinggi bagi pemegang saham. Perusahaan dengan total aset yang besar juga lebih fleksibel dan lebih mudah dalam memperoleh dana dari eksternal perusahaan (Susanti dan Restiana, 2018). Dengan meningkatnya ukuran perusahaan, investor akan memberikan respon positif dan akan meningkatkan nilai perusahaan (Salim dan Susilowaty, 2019). Secara umum, total 
aset perusahaan memiliki nilai yang besar maka penentuan nilai ukuran perusahaan dapat disederhanakan dengan mentransformasikan kedalam logaritma natural (Ghozali, 2016).

(Fajaria dan Isnalita, 2018) dan (Purwanto dan Agustin, 2017) menemukan bahwa ukuran perusahaan berpengaruh positif dan signifikan terhadap nilai perusahaan. Semakin besar ukuran perusahaan, semakin mudah perusahaan mendapatkan pendanaan dari pasar. Investor akan memandang hal ini sebagai sinyal positif yang mendorong peningkatan pada permintaan saham perusahaan, sehingga harga saham meningkat dan nilai perusahaan pun akan meningkat (Purwanto dan Agustin, 2017). Sementara, Susanti dan Restiana (2018) menemukan bahwa ukuran perusahaan memiliki pengaruh negatif dan signifikan terhadap nilai perusahaan. Hal ini berarti ukuran perusahaan yang kecil tetap mempengaruhi keputusan investasi dari investor, sehingga yang terjadi adalah investor melakukan investasi dengan tujuan untuk dapat mengembangkan perusahaan (Susanti dan Restiana, 2018).

Hasil penelitian mereka tidak sejalan dengan (Wimelda dan Siregar, 2017), (Salim dan Susilowati, 2019), (Suwardika dan Mustanda, 2017), serta (Taufan et al., 2018) yang menemukan bahwa ukuran perusahaan tidak berpengaruh terhadap nilai perusahaan.

Good Corporate Governance (GCG). Organization for Economic Co-operations and Development (OECD) (2004) mengungkapkan bahwa Good Corporate Governance (GCG) merupakan hubungan antara manajemen perusahaan, dewan direksi perusahaan, dan pemegang saham, dan para pemangku kepentingan lainnya. GCG menggambarkan pengelolaan manajemen perusahaan yang baik yang meliputi lima elemen, yaitu: transparency, accountability, responsibility, independence, dan fairness (Luthfiah dan Suherman, 2018). Perusahaan yang menerapkan tata kelola yang baik dapat mengurangi potensi konflik kepentingan antara manajer dan pemilik perusahaan, sehingga akan meningkatkan nilai perusahaan (Siagian et al., 2013). Penerapan GCG juga dapat menggambarkan usaha manajemen dalam mengelola kekayaan pemilik perusahaan yang dapat terlihat dari kinerja keuangan perusahaan (Monika dan Khafid, 2016).

(OECD, 2004) menyatakan bahwa sebagai pemegang saham, pemegang saham institusional memiliki peranan untuk meyakinkan bahwa praktek GCG dilakukan dalam perusahaan karena pemegang saham institusional memiliki fiduciary responsibility atas modal yang diinvestasikan dalam perusahaan kepada pihak-pihak yang berkepentingan. (Wimelda dan Siregar, 2017) dalam penelitiannya menemukan bahwa kepemilikan oleh institusi keuangan non bank memiliki pengaruh positif terhadap nilai perusahaan, sementara kepemilikan institusi keuangan dalam bentuk bank tidak memiliki pengaruh terhadap nilai perusahaan. Dengan demikian, penerapan praktek GCG yang diukur dari kepemilikan institusional, dapat meminimalkan risiko pengambilan keputusan yang salah dan mengutamakan kepentingan manajemen, sehingga akan meningkatkan kinerja perusahaan dan memaksimalkan nilai perusahaan (Dewi dan Tarnia, 2011).

(Warapsari dan Suaryana, 2016) dalam penelitiannya menemukan kepemilikan institusional tidak berpengaruh signifikan terhadap nilai perusahaan. Sebaliknya, penelitian (Lestari, 2017) menyebutkan kepemilikan institusional berpengaruh signifikan terhadap nilai perusahaan. Hal ini berarti sebagai pemegang saham, keberadaan kepentingan institusional dapat mengendalikan perilaku manajemen sehingga setiap keputusan yang diambil perusahaan akan sesuai dengan tujuan perusahaan yang pada akhirnya meningkatkan nilai perusahaan. 
Hasil penelitian (Luthfiah dan Suherman, 2018) menunjukkan bahwa kepemilikan institusional tidak mampu memoderasi kinerja keuangan terhadap nilai perusahaan. Keberadaan kepemilikan institusional tidak secara otomatis akan meningkatkan proses pengawasan dalam perusahaan. Hal ini terutama jika kepemilikan institusional merupakan pemegang saham mayoritas, sehingga mereka memegang kendali dan mengambil keputusan yang menguntungkan mereka, sehingga tidak berpengaruh terhadap nilai perusahaan (Luthfiah dan Suherman, 2018). Hasil penelitian mereka tidak sejalan dengan hasil penelitian (Dewi dan Tarnia, 2011) dan (Sunarwijaya, 2016) yang menemukan bahwa kepemilikan institusional dapat memoderasi pengaruh kinerja keuangan terhadap nilai perusahaan.

Kerangka Pemikiran Dan Hipotesis. Kerangka pemikiran dalam penelitian ini dapat dilihat pada Gambar 3 sebagai berikut:

Gambar 3. Kerangka Pemikiran

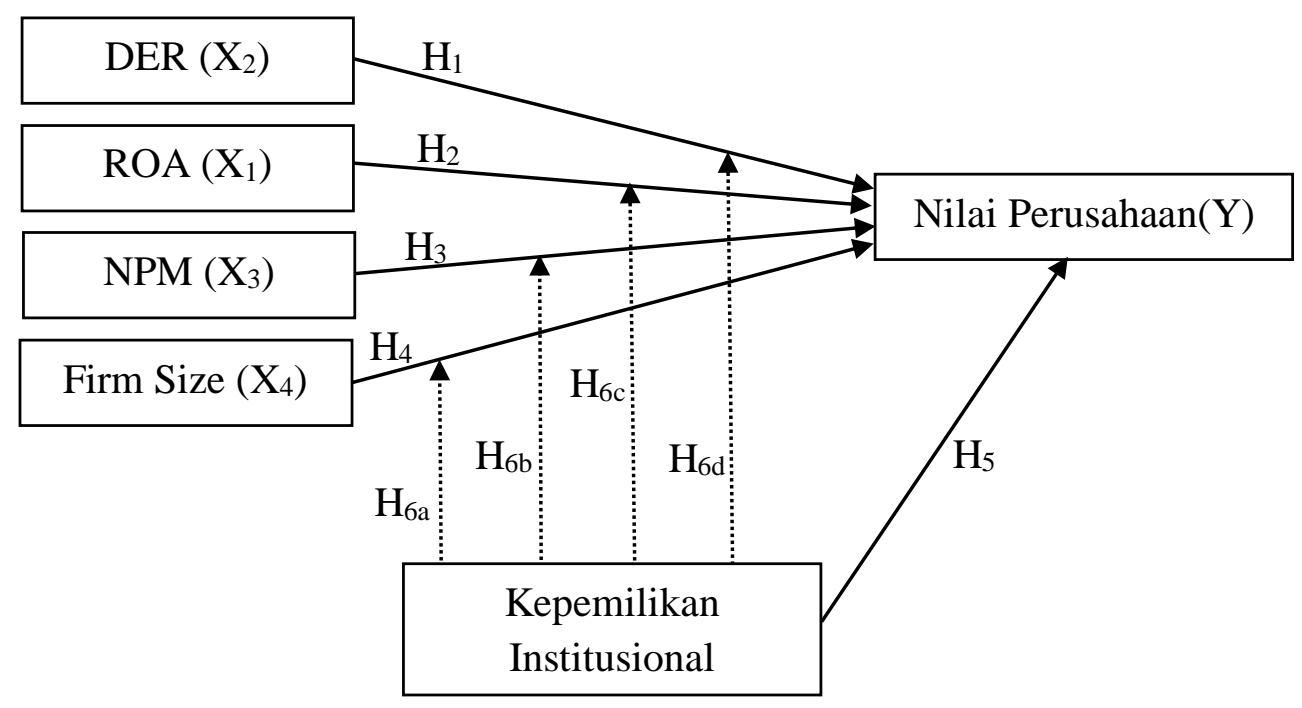

Untuk mendapatkan bukti empiris mengenai pengaruh struktur modal, profitabilitas, ukuran perusahan, dan kepemilikan institusional terhadap nilai perusahaan manufaktur yang terdaftar di BEI tahun 2016-2018 dan untuk melihat kemampuan/peran kepemilikan institusional sebagai variabel moderasi, maka dikembangkan hipotesis sebagai berikut:

$\mathrm{H}_{1}=$ DER berpengaruh signifikan positif terhadap nilai perusahaan

$\mathrm{H}_{2}=$ ROA berpengaruh signifikan positif terhadap nilai perusahaan

$\mathrm{H}_{3}=$ NPM berpengaruh signifikan positif terhadap nilai perusahaan

$\mathrm{H}_{4}=$ Firm Size berpengaruh signifikan positif terhadap nilai perusahaan

$\mathrm{H}_{5}=$ Kepemilikan Institusional berpengaruh signifikan positif terhadap nilai perusahaan 
$\mathrm{H}_{6}=$ Kepemilikan Institusional memoderasi pengaruh positif DER, ROA, NPM, dan Firm Size terhadap nilai perusahaan

\section{METODELOGI}

Populasi dan Teknik Pemilihan Sampel. Populasi dalam penelitian ini ialah perusahaan manufaktur yang terdaftar di BEI periode 2016-2018. Sampel penelitian dipilih dengan metode purposive sampling, yaitu dengan kriteria: perusahaan manufaktur yang terdaftar di BEI, tidak melakukan Initial Public Offering (IPO), tidak delisting, dan tidak mengalami kerugian selama periode 2016-2018, serta memiliki semua variabel yang digunakan dalam penelitian ini. Perusahaan manufaktur yang menjadi sampel penelitian adalah sebanyak 77 perusahaan, sehingga data penelitian yang diolah sebanyak 231 .

\section{Identifikasi dan Pengukuran Variabel}

Tabel 1. Operasional Variabel

\begin{tabular}{l|c|c}
\hline \multicolumn{1}{c|}{ Variabel } & Rumus & Skala \\
\hline Firm Value & PBV $(\mathrm{Y})=\frac{\text { Market Price per Share }}{\text { Book Value per Share }}$ X 100\% & Rasio \\
\hline $\begin{array}{l}\text { Struktur } \\
\text { Modal }\end{array}$ & $\operatorname{DER}\left(\mathrm{X}_{1}\right)=\frac{\text { Total Debt }}{\text { Total Assets }}$ X 100\% & Rasio \\
\hline \multirow{2}{*}{\begin{tabular}{l} 
Profitabilitas \\
\cline { 2 - 3 }
\end{tabular}} & $\operatorname{ROA}\left(\mathrm{X}_{2}\right)=\frac{\text { Net Income }}{\text { Total Assets }} \mathrm{X} \mathrm{100 \%}\left(\mathrm{X}_{3}\right)=\frac{\text { Net Income }}{\text { Net Sales }}$ X 100\% & Rasio \\
\hline $\begin{array}{l}\text { Ukuran } \\
\text { Perusahaan }\end{array}$ & Firm Size $\left(\mathrm{X}_{4}\right)=$ Ln $($ Total Assets $)$ & Rasio \\
\hline $\begin{array}{l}\text { Kepemilikan } \\
\text { Institusional }\end{array}$ & $\frac{\text { Number of shares owned by instituion }}{\text { Number of shares outstanding }}$ X 100\% & Rasio \\
\hline
\end{tabular}

Tabel 1 menunjukkan pengukuran masing-masing variabel yang digunakan dalam penelitian ini. Variabel terikat (Y) dalam penelitian ini adalah nilai perusahaan (firm value) yang diproksikan dengan Price to Book Value/PBV. Penelitian ini memiliki lima variabel bebas (X) yaitu variabel struktur modal yang diproksikan dengan Debt to Equity Ratio/DER $\left(\mathrm{X}_{1}\right)$, variabel profitabilitas yang diproksikan dengan Return on Assets/ROA $\left(\mathrm{X}_{2}\right)$ dan Net Profit Margin/NPM $\left(\mathrm{X}_{3}\right)$, variabel Firm Size $\left(\mathrm{X}_{4}\right)$, dan variabel Good Corporate Governance/GCG yang diproksikan dengan kepemilikan institusional (Institusional Ownership) ( $\left.\mathrm{X}_{5}\right)$. 
Teknik Pengumpulan Data. Data dalam penelitian ini merupakan data sekunder. Data diambil dari Laporan Keuangan Perusahaan Manufaktur yang terdaftar di BEI tahun 20162018 yang diakses melalui website perusahaan, dan melalui website www.idx.co.id dan www.sahamok.com.

Dalam penelitian ini data dikumpulkan dan diolah menggunakan Microsoft Excel 2010 dan Eviews versi 10.0. Analisis data yang dilakukan adalah analisis statistik deskriptif (mean, nilai minimum, nilai maksimum dan standar deviasi), uji asumsi klasik multikolinearitas, dan uji analisis regresi data panel yang meliputi uji common effect, uji fixed effect, dan uji random effect. Untuk menentukan model regresi yang paling tepat untuk penelitian ini, digunakan uji Chow yang membandingkan hasil uji common effect dan fixed effect, uji Hausmann yang membandingkan hasil uji random effect dan fixed effect, dan uji Lagrange-Multiplier yang membandingkan hasil uji random effect dan common effect.

Pengujian hipotesis dalam penelitian ini meliputi uji koefisien determinasi $\left(\mathrm{R}^{2}\right)$, uji statistik $\mathrm{F}$ dan uji statistik parsial (uji t). Semua pengujian dilakukan dengan tingkat signifikansi sebesar $5 \%$.

Model penelitian yang digunakan untuk $\mathrm{H}_{1}, \mathrm{H}_{2}, \mathrm{H}_{3}, \mathrm{H}_{4}$ dan $\mathrm{H}_{5}$ adalah:

$$
\mathrm{PBV}=\alpha+\beta_{1} \mathrm{DER}+\beta_{2} \mathrm{ROA}+\beta_{3} \mathrm{NPM}+\beta_{4} \mathrm{FIRM} \_\mathrm{SIZE}+\beta_{5} \mathrm{INST} \_\mathrm{OWN}+\varepsilon
$$

Sementara, model penelitian untuk $\mathrm{H}_{6}$ adalah:

$$
\begin{gathered}
\text { PBV }=\alpha+\beta_{1} \mathrm{DER}+\beta_{2} \mathrm{ROA}+\beta_{3} \mathrm{NPM}+\beta_{4} \mathrm{FIRM} \text { SIZE }+\beta_{5} \mathrm{INST} \text { OWN } \\
+\beta_{6} \mathrm{DER} * \mathrm{INST} \mathrm{OWN}+\beta_{7} \mathrm{ROA} * \mathrm{INST} \text { OWN }+\beta_{8} \mathrm{NPM}^{*} \mathrm{INST} \mathrm{OWN} \\
+\beta_{9} \text { FIRM_SIZE*INST_OWN }+\varepsilon
\end{gathered}
$$

Keterangan:

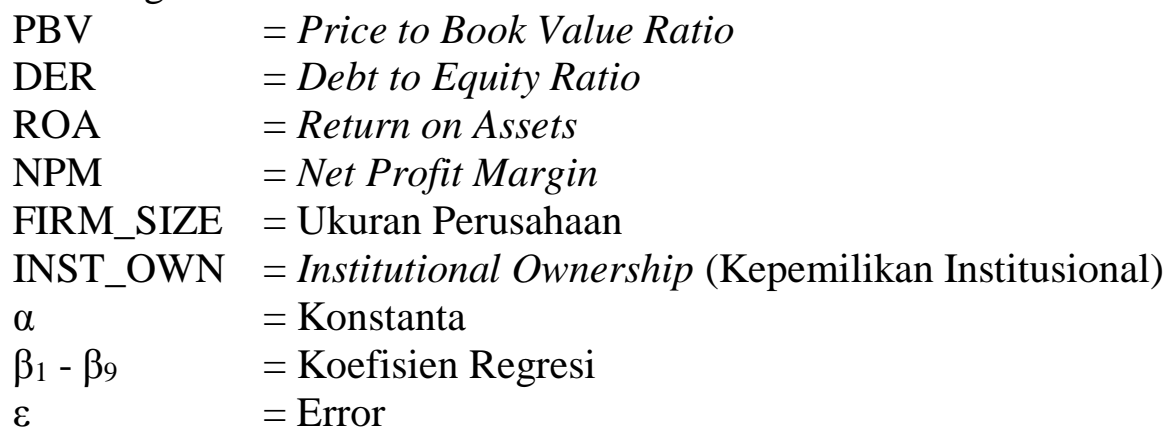




\section{HASIL DAN PEMBAHASAN}

Analisis Statistik Deskriptif. Tabel 2 di bawah ini menunjukkan hasil uji statistik deskriptif atas variabel nilai perusahaan, struktur modal, profitabilitas, ukuran perusahaan, dan kepemilikan institusional. Nilai rata-rata dari PBV sebesar 3,239755 lebih rendah dari standar deviasi 8,290547, yang berarti variabel PBV yang menjadi sampel penelitian memiliki tingkat variasi yang tinggi. Hal ini dapat dilihat dari rentang nilai PBV yang menjadi sampel penelitian, dimana nilai minimum PBV sebesar 0,070115 yang dimiliki oleh PT Nusantara Inti Corpora Tbk di tahun 2017 dan nilai maksimum PBV sebesar 82,44443 yang dimiliki PT Unilever Indonesia Tbk di tahun 2017. Nilai PBV di bawah 1 menunjukkan masih rendahnya nilai pasar saham perusahaan sampel, sementara nilai PBV di atas 1 menunjukkan perusahaan berhasil menciptakan nilai bagi pemegang saham melebihi dari nilai investasi yang dilakukan pemegang saham.

Tabel 2. Hasil Uji Statistik Deskriptif

Sample: 20162018

\begin{tabular}{lcccccc}
\hline \hline & PBV & DER & ROA & NPM & FIRM_SIZE & INST_OWN \\
\hline \hline Mean & 3.239755 & 0.946693 & 0.072871 & 0.077225 & 28.93280 & 0.689490 \\
Median & 1.234149 & 0.712841 & 0.054658 & 0.062970 & 28.65834 & 0.709910 \\
Maximum & 82.44443 & 4.946514 & 0.526704 & 0.445940 & 33.44014 & 0.988410 \\
Minimum & 0.070115 & 0.105166 & 0.000228 & 0.000450 & 25.64046 & 0.016370 \\
Std. Dev. & 8.290547 & 0.772803 & 0.077308 & 0.071785 & 1.576756 & 0.194669
\end{tabular}

Sumber: (Data diolah, 2019)

Variabel DER dalam Tabel 2 memiliki nilai standar deviasi sebesar 0,772803 yang lebih rendah dari nilai rata-rata DER sebesar 0,946693, hal ini mengindikasikan rendahnya variasi variabel DER yang menjadi sampel penelitian. Nilai maksimum DER sebesar 4,946514 mengindikasikan tingginya pendanaan menggunakan hutang dari perusahaan sampel yaitu sebesar 4,946514 kali dari pendanaan dengan ekuitas, dan nilai minimum DER sebesar 0,105166.

Nilai rata-rata variabel ROA sebesar 0,072871 mengindikasikan perusahaan sampel memiliki kemampuan menghasilkan laba yang masih sangat rendah yaitu hanya sebesar $7,2871 \%$ dari total aset yang dimiliki perusahaan. Nilai standar deviasi ROA sebesar 0,077308 yang lebih tinggi dari nilai rata-rata ROA sebesar 0,072871 menunjukkan tingginya variasi variabel ROA dari perusahaan sampel, dimana nilai minimum ROA sebesar 0.000228 dan nilai maksimum ROA sebesar 0.526704 .

Tabel 2 menunjukkan nilai rata-rata variabel NPM sebesar 0,077225 lebih tinggi dari standar deviasi NPM sebesar 0,071785. Nilai rata-rata variabel NPM sebesar 0,077225 juga mengindikasikan perusahaan sampel memiliki kemampuan menghasilkan laba yang masih sangat rendah yaitu hanya sebesar $7,7225 \%$ dari nilai penjualan periode berjalan. Hal ini juga berarti efektivitas dan efisiensi operasional perusahaan sampel belum optimal karena yang mengindikasikan tingginya beban-beban yang terjadi sehingga menyebabkan rendahnya laba bersih yang dihasilkan jika dibandingkan dari nilai penjualan perusahaan. 
Variabel ukuran perusahaan (FIRM_SIZE) memiliki nilai deviasi sebesar 1,576756 yang lebih rendah dari nilai rata-rata sebesar 28,93280, yang berarti rendahnya variasi variabel ukuran perusahaan yang menjadi sampel penelitian yang diukur dari logaritma natural total aset perusahaan. Variabel kepemilikan institusional (INST_OWN) memiliki nilai rata-rata sebesar 0,689490 , mengindikasikan tingginya tingkat kepemilikan institusional sebagai pemegang saham di perusahaan sampel. Nilai rata-rata tersebut juga menunjukkan bahwa kepemilikan institusional di perusahaan sampel sebagian besar merupakan pemegang saham mayoritas dengan kepemilikan di atas $50 \%$. Nilai standar deviasi kepemilikan institusional sebesar 0,194669 lebih rendah dari nilai rata-rata yang berarti rendahnya variasi nilai kepemilikan institusional perusahaan sampel.

\section{Hasil Uji Multikolinearitas}

Tabel 3. Hasil Uji Multikolinearitas

\begin{tabular}{cccccc} 
& DER & ROA & NPM & FIRM_SIZE & INST_OWN \\
\hline \hline DER & 1.000000 & -0.033594 & -0.139172 & 0.060577 & 0.141714 \\
ROA & -0.033594 & 1.000000 & 0.720719 & 0.159110 & 0.175847 \\
NPM & -0.139172 & 0.720719 & 1.000000 & 0.233886 & 0.086459 \\
FIRM_SIZE & 0.060577 & 0.159110 & 0.233886 & 1.000000 & -0.162650 \\
INST_OWN & 0.141714 & 0.175847 & 0.086459 & -0.162650 & 1.000000
\end{tabular}

Sumber: (Data diolah, 2019)

Hasil uji multikolinearitas pada Tabel 3 menunjukkan nilai koefisien korelasi di antara masing-masing variabel bebas di bawah 0,8 yang berarti tidak terjadi multikolinearitas (Ajija et al., 2011).

Pemilihan Model Estimasi. Untuk memilih model estimasi, maka pertama dilakukan uji Chow. Hasil uji Chow dengan menggunakan Eviews 10 menunjukkan nilai probabilitas cross-section chi-square sebesar 0,0000 lebih kecil dari 0,05, yang berarti fixed effect model lebih baik dari common effect model. Pengujian kedua adalah uji Hausman. Hasil uji Hausman menunjukkan nilai probabilitas cross-section random sebesar 0,0000 lebih kecil dari 0,05 , yang berarti fixed effect model lebih baik dari random effect model. Berdasarkan dua hasil uji tersebut, maka model estimasi yang digunakan dalam penelitian ini adalah fixed effect model.

Hasil Uji Regresi Data Panel. Hasil uji regresi data panel menggunakan fixed effect model dapat dilihat pada persamaan regresi di bawah ini:

$$
\begin{aligned}
& \mathrm{PBV}=97,22683+2,007951 \mathrm{DER}-27,77650 \mathrm{ROA}+12,06882 \mathrm{NPM} \\
& -3,243355 \text { FIRM_SIZE }-1,387344 \text { INST_OWN }+\varepsilon \\
& \text { Keterangan: } \\
& \text { PBV = Price to Book Value Ratio } \\
& \text { DER = Debt to Equity Ratio } \\
& \text { ROA = Return on Assets } \\
& \text { NPM } \quad=\text { Net Profit Margin }
\end{aligned}
$$


FIRM_SIZE = Ukuran Perusahaan

INST_OWN = Institutional Ownership (Kepemilikan Institusional)

Dalam persamaan regresi diperoleh nilai konstanta sebesar 97,22683 yang berarti jika DER, ROA, NPM, ukuran perusahaan, dan kepemilikan institusional nol atau tetap, maka nilai perusahaan akan bertambah 97,22683 satuan. Koefisien regresi DER menunjukkan nilai positif yang berarti jika DER mengalami kenaikan satu satuan sementara variabel bebas lainnya nol atau tetap maka nilai perusahaan akan bertambah sebesar 2,007951 satuan. Variabel NPM juga memiliki koefisien regresi positif, yang berarti jika NPM meningkat satu satuan dan variabel bebas lainnya nol atau tetap maka nilai perusahaan akan bertambah sebesar 12,06882 satuan.

Koefisien regresi variabel ROA -27,77650 yang mengindikasikan jika nilai ROA meningkat satu satuan dan variabel bebas lainnya nol atau tetap maka nilai perusahaan akan menurun sebesar 27,77650 satuan. Ukuran perusahaan dengan nilai koefisien regresi 3,243355 mengindikasikan apabila ukuran perusahaan meningkat satu satuan dan variabel bebas lainnya nol atau tetap, akan menurunkan nilai perusahaan 3,243355 satuan. Nilai negatif koefisien regresi variabel kepemilikan institusional juga mengindikasikan peningkatan satu satuan pada kepemilikan institusional akan menurunkan nilai perusahaan 1,387344 satuan.

Nilai probabilitas untuk uji $\mathrm{F}$ dapat dilihat pada Tabel 4 sebesar 0,000000. Hasil tersebut lebih kecil dari 0.05, yang menunjukkan bahwa model regresi dalam penelitian ini sudah memenuhi kelayakan model, dimana DER, ROA, NPM, Firm Size, dan Kepemilikan Institusional secara bersama-sama memiliki pengaruh signifikan terhadap Nilai Perusahaan.

Tabel 4 menunjukkan Nilai koefisien determinasi $\left(\mathrm{R}^{2}\right)$ sebesar 0.930423 atau 93,04\% yang berarti bahwa variabel struktur modal (DER), profitabilitas (ROA dan NPM), ukuran perusahaan, dan kepemilikan institusional dapat menjelaskan nilai perusahaan sebesar 93,04\%. 6,96\% dari nilai perusahaan dapat dijelaskan oleh variabel lain yang tidak dimasukkan dalam penelitian ini.

\section{Hasil Uji Hipotesis dan Pembahasan}

Tabel 4. Hasil Uji Regresi Data Panel

\begin{tabular}{crrrr}
\hline \hline Variable & Coefficient & Std. Error & \multicolumn{1}{c}{ t-Statistic } & \multicolumn{1}{c}{ Prob. } \\
\hline \hline C & 97.22683 & 36.64940 & 2.652890 & 0.0088 \\
DER & 2.007951 & 0.630953 & 3.182412 & 0.0018 \\
ROA & -27.77650 & 7.205029 & -3.855154 & 0.0002 \\
NPM & 12.06882 & 5.436289 & 2.220048 & 0.0279 \\
FIRM_SIZE & -3.243355 & 1.255995 & -2.582299 & 0.0108 \\
INST_OWN & -1.387344 & 2.713452 & -0.511284 & 0.6099 \\
\hline \hline R-squared & 0.954926 & & & \\
Adjusted R-squared & 0.930423 & & & \\
Prob(F-statistic) & 0.000000 & & & \\
\hline
\end{tabular}

Sumber: (Data diolah, 2019) 
Nilai koefisien regresi untuk variabel DER pada Tabel 4 sebesar 2,007951 dengan tingkat signifikansi sebesar 0,0018 lebih kecil dari 0,05, yang berarti $\mathrm{H}_{1}$ dapat diterima. Struktur modal yang diproksikan dengan DER memiliki pengaruh positif dan signifikan terhadap nilai perusahaan. Nilai koefisien yang positif mengindikasikan bahwa semakin tinggi nilai DER maka nilai perusahaan juga akan semakin tinggi. Perusahaan yang memiliki hutang harus membayar bunga dan mengurangi laba sebelum pajak (Earnings Before Tax/EBT) sehingga akan mengurangi beban pajak bagi perusahaan yang disebut juga dengan efek tax deductible (Yastini dan Mertha, 2015). Efek tersebut dapat menjadi sinyal positif bagi investor, sehingga akan mendorong meningkatnya nilai pasar saham dan nilai perusahaan.

Peningkatan nilai hutang perusahaan dapat memberikan pengaruh positif pada nilai perusahaan karena mengindikasikan adanya kepercayaan dari investor bahwa perusahaan memiliki kemampuan untuk membayar hutang sehingga memberikan rasa aman kepada investor. Selain itu, investor memandang bahwa keputusan pendanaan dengan menggunakan hutang akan memberikan manfaat yang lebih besar daripada beban yang timbul atas hutang. Pemegang saham juga memiliki rasa aman, karena penambahan hutang berarti tidak ada penambahan saham beredar, sehingga laba per saham akan meningkat dan dapat memberikan pengaruh positif terhadap nilai pasar saham dan nilai perusahaan.

Hasil penelitian ini sejalan dengan hasil penelitian (Chasanah dan Adhi, 2017), (Indasari dan Yadnyana, 2018), (Susanti dan Restiana, 2018), serta (Wahyu dan Mahfud, 2018) yang menemukan bahwa struktur modal memiliki pengaruh positif dan signifikan terhadap nilai perusahaan. Hasil penelitian ini belum sejalan dengan penelitian (Purwanto dan Agustin, 2017), (Lubis et al., 2017) serta (Salim dan Susilowati, 2019).

Profitabilitas diproksikan dengan ROA dan NPM. Dalam Tabel 4, variabel ROA memiliki nilai koefisien -27,77650 dengan tingkat signifikansi $0,0002 . \mathrm{H}_{2}$ tidak dapat diterima, dimana ROA berpengaruh signifikan negatif terhadap nilai perusahaan. Peningkatan pada nilai ROA akan menurunkan nilai perusahaan. Hasil penelitian ini sejalan dengan hasil penelitian (Munawaroh dan Priyadi, 2014) dan (Yastini dan Mertha, 2015) yang menyatakan ROA berpengaruh negatif dan signifikan terhadap nilai perusahaan. Namun, hasil penelitian (Chasanah dan Adhi, 2017), (Indasari dan Yadnyana, 2018), (Salim dan Susilowati, 2019), (Suwardika dan Mustanda, 2017), (Taufan et al., 2018), serta (Wahyu dan Mahfud, 2018) menemukan bahwa ROA memberikan pengaruh positif dan signifikan terhadap nilai perusahaan.

Nilai ROA yang tinggi dapat meningkatkan laba per lembar saham tetapi tidak langsung menjadi sinyal positif bagi investor karena perusahaan dapat menahan sebagian besar laba yang dihasilkan dan tidak dibagikan sebagai deviden. Jika perusahaan menahan sebagian besar labanya dalam laba ditahan, nilai buku perusahaan akan mengalami kenaikan. Dengan demikian, kenaikan ROA tidak mendorong kenaikan harga saham dan dapat menurunkan nilai perusahaan.

Variabel NPM memiliki nilai koefisien regresi positif sebesar 12,06882 dengan tingkat signifikansi $0,0279 . \mathrm{H}_{3}$ dapat diterima yang berarti NPM memberikan pengaruh positif dan signifikan terhadap nilai perusahaan. Peningkatan pada nilai NPM akan mendorong peningkatan pada nilai perusahaan. Kenaikan pada nilai NPM mengindikasikan perusahaan memiliki kinerja profitabilitas yang positif dan menjadi sinyal positif bagi investor sehingga mendorong harga saham naik dan nilai perusahaan meningkat. Hasil 
penelitian ini sejalan dengan hasil penelitian (Munawaroh dan Priyadi, 2014) dan (Wahyu dan Mahfud, 2018), namun tidak sejalan dengan hasil penelitian Hasil penelitian (Susanti dan Restiana, 2018) menemukan bahwa NPM memberikan pengaruh negatif dan signifikan.

Variabel profitabilitas dalam penelitian ini diproksikan dengan ROA dan NPM, namun memberikan hasil penelitian yang berbeda dimana ROA memberikan pengaruh signifikan negatif dan NPM memberikan pengaruh signifikan positif terhadap nilai perusahaan. Kondisi ini mengindikasikan bahwa investor lebih melihat NPM sebagai faktor yang memberikan pengaruh terhadap kenaikan nilai perusahaan. Investor mengukur kinerja positif perusahaan dari kemampuan manajemen dalam menghasilkan laba berdasarkan hasil operasional yang efektif dan efisien. Investor tidak melihat pada kemampuan perusahaan dalam menghasilkan laba berdasarkan penggunaan aset, karena aset perusahaan tidak seluruhnya didanai dari internal perusahaan (pemegang saham), tetapi juga dari pendanaan pihak luar yaitu melalui perolehan hutang.

Pada Tabel 4 dapat dilihat nilai koefisien regresi untuk ukuran perusahaan (firm size) menunjukkan nilai -3,243355 dengan tingkat signifikansi 0,0108. Hal ini berarti $\mathrm{H}_{4}$ ditolak, dimana variabel ukuran perusahaan memiliki pengaruh negatif dan signifikan terhadap nilai perusahaan. Kondisi ini mengindikasikan bahwa apabila total aset perusahaan meningkat maka akan menurunkan nilai perusahaan. Hasil penelitian ini tidak sejalan dengan hasil penelitian (Fajaria dan Isnalita, 2018) dan (Purwanto dan Agustin, 2017), tetapi sejalan dengan (Susanti dan Restiana, 2018) yang menyatakan bahwa ukuran perusahaan memiliki pengaruh negatif dan signifikan terhadap nilai perusahaan. Hasil penelitian ini menunjukkan bahwa ukuran perusahaan yang diukur dari logaritma natural total aset perusahaan bukan menjadi faktor yang dapat meningkatkan nilai perusahaan.

Kepemilikan institusional memiliki koefisien regresi sebesar -1,387344 dengan tingkat signifikansi 0,6099 yang lebih besar dari 0,05. $\mathrm{H}_{5}$ ditolak, dengan hasil kepemilikan institusional memiliki pengaruh negatif dan tidak signifikan terhadap nilai perusahaan. Dalam teori agensi, kepemilikan institusional memegang peran dalam mengawasi kinerja manajemen sehingga akan menekan masalah keagenan dan mengurangi biaya agensi. Hasil penelitian ini bertolak belakang dengan teori agensi, yang berarti tidak berjalannya peran pengawasan dari kepemilikan institusional sehingga berdampak pada penurunan nilai perusahaan.

Hasil penelitian ini juga menunjukkan bahwa keberadaan kepemilikan institusional sebagai pemegang saham belum menjadi sinyal positif bagi investor. Hal ini dapat terjadi jika kepemilikan institusional merupakan pemegang saham mayoritas yang memiliki kemampuan mempengaruhi pengambilan keputusan di perusahaan, dimana keputusan tersebut menguntungkan pemegang saham mayoritas. Hasil penelitian ini sejalan dengan penelitian (Warapsari dan Suaryana, 2016) tetapi bertolak belakang dengan penelitian (Lestari, 2017) yang menemukan bahwa kepemilikan institusional berpengaruh signifikan terhadap nilai perusahaan. 


\section{Hasil Uji Regresi Moderasi}

Tabel 5. Hasil Uji Regresi Moderasi

\begin{tabular}{crrrr}
\hline \hline Variable & Coefficient & Std. Error & \multicolumn{1}{c}{ t-Statistic } & \multicolumn{1}{l}{ Prob. } \\
\hline \hline C & 117.4812 & 47.21741 & 2.488092 & 0.0140 \\
DER & 5.988046 & 3.556257 & 1.683806 & 0.0944 \\
ROA & 20.41089 & 33.10005 & 0.616642 & 0.5384 \\
NPM & 22.29327 & 26.05598 & 0.855591 & 0.3936 \\
FIRM_SIZE & -4.113567 & 1.655863 & -2.484244 & 0.0141 \\
INST_OWN & -33.33578 & 47.33453 & -0.704259 & 0.4824 \\
DERINST & -4.504966 & 3.966663 & -1.135707 & 0.2580 \\
ROAINST & -64.85893 & 42.12418 & -1.539708 & 0.1258 \\
NPMINST & -13.74817 & 32.99649 & -0.416655 & 0.6775 \\
FIRMSIZEINST & 1.311453 & 1.661728 & 0.789210 & 0.4313 \\
\hline \hline
\end{tabular}

Sumber: (Data diolah, 2019)

Hasil uji regresi moderasi dapat dilihat pada Tabel 5. Nilai probabilitas untuk seluruh variabel bebas dengan kepemilikan institusional sebagai variabel moderasi menunjukkan nilai signifikansi di atas 0,05 . Dengan demikian $\mathrm{H}_{6}$ tidak dapat diterima, sehingga dapat disimpulkan bahwa kepemilikan institusional tidak dapat memoderasi pengaruh antara DER, ROA, NPM dan ukuran perusahaan terhadap nilai perusahaan. Peran kepemilikan institusional dalam mengawasi kinerja manajemen dan mengharmonisasikan hubungan antara manajemen dengan pemilik tidak terbukti mampu mempengaruhi nilai perusahaan.

(Luthfiah dan Suherman, 2018), (Wijaya and Linawati, 2015), serta (Heder and Priyadi, 2017) menemukan bahwa kepemilikan institusional tidak mampu memoderasi kinerja keuangan terhadap nilai perusahaan. Kondisi ini dapat terjadi ketika investor yaitu kepemilikan institusional memiliki hubungan keluarga dengan manajemen perusahaan, sehingga akan terbentuk opini bahwa manajemen akan mengambil keputusan yang menguntungkan kepemilikan institusional (Heder dan Priyadi, 2017). Hal ini menyebabkan pasar memberikan respon negatif dan tidak meningkatkan nilai pasar dan nilai perusahaan. Tingginya kepemilikan institusional sebagai bagian dari pemegang saham juga tidak secara otomatis akan menambah tingkat pengawasan dalam perusahaan (Wijaya dan Linawati, 2015). Namun, hasil penelitian ini bertolak belakang dengan hasil penelitian (Dewi dan Tarnia, 2011) dan (Sunarwijaya, 2016) yang menemukan bahwa kepemilikan institusional dapat memoderasi pengaruh kinerja keuangan terhadap nilai perusahaan.

\section{KESIMPULAN}

Hasil penelitian terhadap perusahaan menufaktur yang terdaftar di BEI tahun 20162018 menunjukkan bahwa struktur modal yang diproksikan dengan DER dan profitabilitas yang diproksikan dengan NPM secara parsial memiliki pengaruh positif dan signifikan terhadap nilai perusahaan. Sementara, profitabilitas yang diproksikan dengan ROA, ukuran perusahaan, dan kepemilikan institusional secara parsial memiliki pengaruh negatif dan signifikan terhadap nilai perusahaan. DER, ROA, NPM, ukuran perusahaan, dan 
kepemilikan institusional secara bersama-sama memberikan pengaruh signifikan terhadap nilai perusahaan. Sebagai variabel moderasi, GCG yang diproksikan dengan kepemilikan institusional terbukti tidak dapat memoderasi pengaruh positif dan signifikan dari struktur modal, profitabilitas, dan ukuran perusahaan terhadap nilai perusahaan.

Hasil dalam penelitian ini belum menjadi hasil yang dapat digeneralisasi atas pengaruh struktur modal, profitabilitas, ukuran perusahaan, dan kepemilikan institusional terhadap nilai perusahaan. Penelitian ini menggunakan sampel data perusahaan manufaktur yang terdaftar di BEI tahun 2016-2018. Untuk penelitian selanjutnya sampel data penelitian dapat diperluas pada sampel perusahaan non manufaktur dan menambah tahun sampel penelitian. Hasil koefisien determinasi dalam penelitian ini mengindikasikan 6,96\% dari nilai perusahaan tidak dapat dijelaskan oleh struktur modal, profitabilitas, ukuran perusahaan, dan GCG yang diproksikan dengan kepemilikan institutisonal. Penelitian selanjutnya dapat menambah variabel lain yang dapat mempengaruhi nilai perusahaan.

\section{DAFTAR PUSTAKA}

Ajija, R., D. W. Sari, R. H. Setianto, dan M. R. Primanti. (2011). Cara Cerdas Menguasai Eviews. Jakarta: Salemba Empat.

Chasanah, A.N. dan D. K. Adhi. (2017). Profitabilitas, Struktur Modal Dan Likuiditas Pengaruhnya Terhadap Nilai Perusahaan Pada Perusahaan Real Estate Yang Listed di BEI Tahun 2012-2015. Fokus Ekonomi, Vol. 12 No. 2, Desember 2017: 131-146.

Dewi, R. R. dan T. Tarnia. (2011). Pengaruh Kinerja Keuangan Terhadap Nilai Perusahaan dengan Good Corporate Governance Sebagai Variabel Moderasi. Jurnal Informasi, Perpajakan, Akuntansi, dan Keuangan Publik, Vol. 6 No. 2, Juli 2011: 115-132.

Fahmi, Irham. (2015). Analisis Laporan Keuangan. Cetakan Ke-2. Bandung: Alfabeta.

Fajaria, A. Z. dan Isnalita. (2018). The Effect of Profitability, Liquidity, Leverage and Firm Growth of Firm Value with its Dividend Policy as a Moderating Variable. International Journal of Managerial Studies and Research (IJMSR), Volume 6 Issue 10, October 2018: 55-69, ISSN 2349-0330 (Print) \& ISSN 2349-0349 (Online). DOI: http://dx.doi.org/10.20431/2349-0349.0610005.

Ghozali, Imam. (2016). Aplikasi Analisis Multivariete Dengan Program IBM SPSS 23 (Edisi 8). Cetakan ke VIII. Semarang: Badan Penerbit Universitas Diponegoro.

Hansen, Verawati dan Juniarti. (2014). Pengaruh Family Control, Size, Sales Growth dan Leverage Terhadap Profitabilitas dan Nilai Perusahaan Pada Sektor Perdagangan, Jasa, dan Investasi. Business Acounting Review, Vol. 2, No. 1, 2014.

Heder dan M. P. Priyadi. (2017). Pengaruh Kinerja Keuangan Terhadap Nilai Perusahaan dengan Good Corporate Governance sebagai Variabel Pemoderasi. Jurnal Ilmu dan Riset Akuntansi, Vol. 6, No. 7.

Indasari, A. P. dan I. K. Yadnyana. (2018). Pengaruh Profitabilitas, Growth Opportunity, Likuiditas, Dan Struktur Modal Pada Nilai Perusahaan. E-Jurnal Akuntansi Universitas Udayana, Vol.22.1, Januari (2018): 714-746. ISSN: 2302-8556. DOI: https://doi.org/10.24843/EJA.2018.v22.i01.p27.

Jensen, M. C. dan W. H. Meckling. (1976). Theory of Firm: Managerial Behavior, Agency Costs and Ownership Structure. Journal of Financial Economics, Vol. 3 No. 4: 305360. 
Lestari. (2017). Pengaruh Kepemilikan Institusional Dan Struktur Modal Terhadap Nilai Perusahaan. Jurnal Riset Manajemen dan Bisnis (JRMB) Fakultas Ekonomi UNIAT Vol.2, S1, September 2017: 293 - 306.

Lubis, I. L., B. M. Sinaga, dan H. Sasongko. (2017). Pengaruh Profitabilitas, Struktur Modal, dan Likuiditas Terhadap Nilai Perusahaan. Jurnal Aplikasi Bisnis dan Manajemen, Vol. 3 No. 3, September 2017: 458-465. DOI: http://dx.doi.org/10.17358/jabm.3.3.458.

Luthfiah, A. A., and Suherman. (2018). The Effects of Financial Performance Toward Firm Value With Ownership Structure as Moderating Variable (The Study on Manufacturing Companies Listed in Indonesia Stock Exchange In The Period of 2012-2016). Journal of Business and Behavioural Entrepreneurship, 2(1): 18-27. DOI: https://doi.org/10.21009/JOBBE.002.1.03

Manurung, S. D., Suhadak, dan N. F. Nuzula. (2014) The Influence of Capital Structure on Profitability and Firm Value, Jurnal Administrasi Bisnis (JAB), Vol. 7 No. 2.

Monika, L. T. dan M. Khafid. (2016). The Effect of Financial Performance on Corporate Value with CSR Disclosure and GCG Mechanism as Moderating Variables. Accounting Analysis Journal (AAJ), Vol. 5 (3), 2016: 197-204. DOI: http://journal.unnes.ac.id/sju/index.php/aaj.

Munawaroh, A. dan M. P. Priyadi. (2014). Pengaruh Profitabilitas Terhadap Nilai Perusahaan dengan Corporate Social Responsibility sebagai Variabel Moderating. Jurnal Ilmu dan Riset Akuntansi, Vol. 3 No. 4 (2014).

Organisation for Economic Co-Operation and Development (OECD). (2004). OECD Principles of Corporate Governance. (Retrieved from: www.oecd.org/dataoecd/32/18/31557724.pdf/12 November 2015).

Penman, S. H. (2003). Financial Statement Analysis And Security Valuation. Mc. Graw Hill, second edition.

Purwanto and J. Agustin. (2017). Financial Performance towards Value of Firms in Basic and Chemicals Industry, European Research Studies Journal, Volume XX, Issue 2A, 2017.

Rajhans, R. K. (2013). Financial Determinant of Firm's Value Evidence From Indian Firms. ZENITH International Journal of Business Economics \& Management Research (ZIJBEMR), Vol. 3 (5), May 2013.

Salim, M. N. dan R. Susilowati. (2019). The Effect of Internal Factors on Capital Structure and Its Impact on Firm Value: Empirical Evidence From The Food and Beverages Industry Listed on Indonesia Stock Exchange 2013-2017. International Journal of Engineering Technologies and Management Research, Vol. 6 (Iss. 7), July 2019: 173191. DOI: $10.5281 /$ zenodo.3359550.

Sartono, A. (2010). Financial Management Theory and Application. BPFE: Yogyakarta.

Siagian, F., S. V. Siregar, dan Y. Rahadian. (2013). Corporate Governance, Reporting Quality, and Firm Value: Evidence from Indonesia. Journal of Accounting in Emerging Economies. Vol. 3 No. 1: 4-20.

Sujoko dan U. Soebiantoro. (2007). Pengaruh Kepemilikan Saham Leverage, Faktor Intern Dan Ekstern Terhadap Nilai Perusahaan (Studi Empiris Pada Perusahaan Manufaktur Di Bursa Efek Indonesia). Jurnal Manajemen dan Kewirausahaan, 9 (1): 41-48. 
Sunarwijaya, I. K. (2016). Pengaruh Kepemilikan Institusional pada Hubungan Positif Antara Profitabil-itas dan Nilai Perusahaan. Jurnal Ilmiah Akuntansi, Vol. 1 No. 2: 93-108.

Susanti, N. dan N. G. Restiana. (2018). What's The Best Factor to Determining Firm Value? Jurnal Keuangan dan Perbankan, 22(2): 301-309.

Sutrisno. (2016). Capital Structure Determinants and Their Impact on Firm Value: Evidence From Indonesia. Economics World, July-Aug. 2016 Vol. 4 No. 4: 179-186. DOI: 10.17265/2328-7144/2016.04.003.

Suwardika, I. N. A., dan I. K. Mustanda. (2017). Pengaruh Leverage, Ukuran Perusahaan, Pertumbuhan Perusahaan, Dan Profitabilitas Terhadap Nilai Perusahaan Pada Perusahaan Properti. E-Jurnal Manajemen Unud, Vol. 6 No. 3, 2017: 1248-1277. ISSN : 2302-8912.

Taufan, A. Rizki, dan M. A. Budianto. (2018). The Effect Of Profitability, Solvability And Company Size On The Company Value. Jurnal Akuntansi Trisakti, ISSN : 2339-0832 (Online), Volume. 5 Nomor. 2 September 2018: 215-224. DOI: http://dx.doi.org/10.25105/jat.v5i2.4865.

Vintila, G. dan C. Gherghina. (2014). The Influence of Financial Intermediaries' Ownership on Firm Value: Empirical Evidence for the Companies Listed on the Bucharest Stock Exchange, Procedia Economics and Finance, 15: 959-967.

Wahyu, D. D. dan M. K. Mahfud. (2018). Analisis Pengaruh Net Profit Margin, Return On Assets, Total Assets Turnover, Earning Per Share, Dan Debt To Equity Ratio Terhadap Nilai Perusahaan (Studi Pada : Perusahaan Manufaktur Yang Terdaftar Di Bursa Efek Indonesia Periode 2010-2016). Diponegoro Journal Of Management. Volume 7 Nomor 2 Tahun 2018. DOI: http://ejournals1.undip.ac.id/index.php/dbr.

Warapsari, A. A. A. U. dan I G.N. A. Suaryana. (2016). Pengaruh Kepemilikan Manajerial Dan Institusional Terhadap Nilai Perusahaan Dengan Kebijakan Utang Sebagai Variabel Intervening. E-Jurnal Akuntansi Universitas Udayana Vol.16.3. September (2016): 2288-2315.

Wijaya, A. and N. Linawati. (2015). Pengaruh Kinerja Keuangan Terhadap Nilai Perusahaan. FINESTA, Vol. 3 No. 1: 46-51.

Wimelda, L. dan S. V. Siregar. (2017). The Effect of Financial Institution Ownership on Firm Value. Corporate Ownership and Control, Volume 14, Issue 2, Winter 2017: 114-122.

Yastini, N. P. Y. A. dan I. M. Mertha. (2015) Pengaruh Faktor Fundamental Terhadap Nilai Perusahaan di Bursa Efek Indonesia. E-Jurnal Akuntansi Universitas Udayana, 11.2: 356-369.

https://industri.kontan.co.id/news/sektor-manufaktur-ini-jadi-andalan-di-tahun-2018. https://www.bi.go.id/publikasi/survei/Prompt-Manufacturing-Index/ Default.aspx. https://www.bi.go.id/id/publikasi/survei/Prompt-Manufacturing-Index/Pages/pmitriwulan-IV-2019.aspx. 